\title{
TRANSITIONAL SOIL CHARACTERISTICS OF ULTISOLS AND SPODOSOLS IN THE SUBALPINE FOREST OF TAIWAN
}

\author{
Zens-Yei Hseu', Chen-Chi Tsai ${ }^{2}$, Ching-Wei Lin'², and Zuens-Sans Chen ${ }^{2}$
}

This study examined the illuviation of clay and spodic materials in three Ultic Haplorthods derived from fine-textured materials from the Alishan Mountain of central Taiwan. Soil analysis, including field description, physical and chemical analyses, and micromorphological studies, was used to study the soils. The soil colors are close to $7.5 \mathrm{YR} 5 / 6$ in all subsurface horizons, with different degrees of spodic material accumulation. Various clay coatings and pellet-like aggregates were found in all subsurface horizons, which satisfied the morphological and chemical criteria for a spodic horizon (Bhs) as defined in Soil Taxonomy. The illuvial clay coatings have relatively weak birefringence but are masked by organo-metallic complexes. Spodosols were found locally to have a thick organic layer, which may intensify the podzolization process. We hypothesized that $\mathrm{Fe}$ and $\mathrm{Al}$ were chelated by organic matter in the surface portion of the pedon to form organo-metallic complexes. The translocation of clay occurred before the illuviation of organo-metallic complexes in the subsurface horizons during soil development. The slow accumulation of organic-metallic complexes in the Bhs horizons within the 50$\mathrm{cm}$ depth is attributed to fine texture and less porosity. The soils derived from two pedogenic processes to show the transitional status between Ultisols and Spodosols that the argillic horizon is overlain by the spodic horizon. (Soil Science 2004;169:457-467)

Key words: Transitional soil, Ultisol, Spodosol, clay illuviation, podzolization.

CPDOSOLS generally have a surface horizon of accumulated organic matter, a bleached eluvial horizon, and a reddish or brown-black illuvial spodic horizon (Muir, 1961; Rourke et al., 1988; Lundstrom et al., 2000). Infiltrating water plays an important role in leaching processes, so Spodosol profiles usually form in humid or perhumid climates (McKeague et al., 1983). These soils are often found not only in loamy or coarse materials but also in subpolar and alpine climatic regimes; however, in some areas, they extend into the interiors of midlatitude continents (Padley et al., 1985; Li et al., 1998).

'Department of Environmental Science and Engineering, National Pingtung University of Science and Technology, Pingtung, 91201 Taiwan ROC.

2Department of Agricultural Chemistry, National Taiwan University, Taipei 106-17,

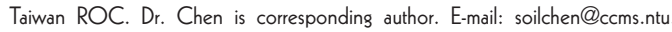
edu.tw

Received Jan. 12, 2004; accepted March 24, 2004

DOI: 10.1097/01.ss.0000131231.35979.f0
Several processes have been proposed to explain podzolization: (i) formation and downward transport of complexes of organic acids with $\mathrm{Al}$ and Fe (De Coninck, 1980), (ii) silicate weathering followed by downward transport of $\mathrm{Al}$ and $\mathrm{Si}$ as inorganic colloidal sols (Jakobsen, 1991), and (iii) $\mathrm{Al}$, and probably $\mathrm{Fe}$, are first translocated into the B horizon as proto-imogolite sols (Farmer, 1982). Although theories of illuviation of spodic materials have largely emphasized chemical processes rather than clay translocation, some studies have demonstrated clay-particle as well as chemical migration of organo-metal complexes in podzolic soils (Fridland, 1958; Guillet et al., 1975; Alekseyev, 1983; Miller, 1983; Harris and Hollien, 1999).

The texture of the parent material and the drainage condition strongly influence the direction of soil development on the Coastal Plain of the eastern United States, explaining why the two most commonly used pedogenic pathways 
have resulted in distinctly different soils: Ultisols with spodic (Bhs) horizons and Spodosols with argillic (Bt) horizons (Markewich and Pavich, 1991). According to Bockheim et al. (1992), well drained soils developed progressively from Typic Troporthods to Typic Haplohumults on the marine terraces of southwestern Oregon. Guillet et al. (1975) indicated that illuviation of clay can promote the differentiation of podzol horizons and that podzolization is strongly redistributive in a Podzol, which demonstrated the clay accumulation in the upper parts of spodic horizons under a texture class of sand and a heath vegetation. Righi et al. (1990) indicated that active organic complexes could easily be accumulated on the soil surface, then translocated, and subsequently formed as spodic materials in the lower portion of an Oxisol-Spodosol sequence of Amazonia, Brazil.

Taiwan has both a tropical and subtropical climate, and Ultisols and Spodosols are found in the subalpine and alpine forests in udic or perudic soil moisture regimes and in a mesic soil temperature regime with heavy rainfall $(>3000 \mathrm{~mm}$ / yr). However, Spodosols generally form at the flatter summit and backslope in microrelief (Li et al., 1998). Some studies have identified the pedogenic processes of Spodosols in the subalpine forests of the Central Ridge of Taiwan (Chen et al., 1989; Chen et al., 1995; Li et al., 1998). Li et al. (1998) and Lin et al. (2002) also indicate that both spodic material formation and clay translocation have occurred in the Bhs horizons of loamy Spodosols in central Taiwan.

Spodosols of Taiwan differ significantly from those of North American and European countries in terms of soil texture and precipitation. Taiwan's Spodosols are developed in fine-textured materials such as shale and slate and also in transported materials under heavy annual rainfall, which intensifies the lessivage and leaching processes. Clay contents in the studied Spodosol or Podzolic soils are generally more than 30\%, and both podzolization and clay illuviation occur in these soils of Taiwan (Chen et al., 1989, 1995; Li et al., 1998; Hseu et al., 1999; Lin et al., 2002). Van Ranst et al. (1997) also found cool tropical Podzols in Rwanda, Central Africa, an area characterized by a cool isomesic soil temperature regime that prevails at high elevations in areas with parent materials of quartzites and micaceous sandstones along steep slopes. Understanding the transition between Ultisols and Spodosols by illuviation of clay and spodic materials in the subalpine forests of central Taiwan is important for establishing the mechanism of podzolization. Therefore, the objectives of this study are to: (i) describe the field morphology and micromorphology related to spodic materials and clay illuviation in the fine-textured soils of Taiwan, (ii) interpret the formation of spodic material and clay illuviation in the subsurface horizon of subalpine forest soils, and (iii) evaluate the pedogenic processes at the study area.

\section{MATERIALS AND METHODS}

\section{Site Description}

Alishan Mountain, an important subalpine area for forest resource conservation in Taiwan, is located in Chayi County in the central-west part of Taiwan. The subalpine forest soils at 1500 to $3000 \mathrm{~m}$ elevation are derived from marine argillaceous sediments and interstratified sandstone and shale of the late Miocene to early Pliocene age. The overstory vegetation is dominated by red cypress (Chamaecyparis formosensis) and, to a lesser extent, by pine (Pinus armandii). The understory vegetation contains Yushania niitakayanensis, Polygonum Chinese Linn, and Miscanthus floridulus. Based on the climate data of the Alishan Metrological Station for the past three decades (Lin et al., 2002), the annual rainfall is about $4000 \mathrm{~mm}$ and most of it falls from May to September. The mean annual air temperature is $10.6^{\circ} \mathrm{C}$. The soil moisture regime is udic or perudic, and the soil temperature regime is mesic in the study area.

Three representative pedons were selected from the coniferous forest with slopes ranging from 3 to 9\% (Fig. 1 and Table 1). Pedon 901, with a $5 \%$ slope, was located at the shoulder position of the landscape, and pedons 902 and 903 were located at the lower backslope. Soil morphological characteristics were described based on the U.S. soil survey manual (Soil Survey Staff, 1993).

\section{Soil Analysis}

Soil samples were collected for physical and chemical analyses from each horizon. Bulk density was determined by the core method (Blake and Hartge, 1986). Particle size distribution was determined by the pipette method (Gee and Bauder, 1986). The $\mathrm{pH}$ of air-dried samples $(<2 \mathrm{~mm})$ was determined in a mixture of soil/deionized water (1:1) by glass electrode (McLean, 1982). Organic carbon (OC) content was measured by the Walkley-Black wet oxidation method (Nelson and Sommers, 1982). Cation exchange capacity and exchangeable bases were measured with the ammonium acetate method ( $\mathrm{pH}$ 7.0) (Rhoades, 

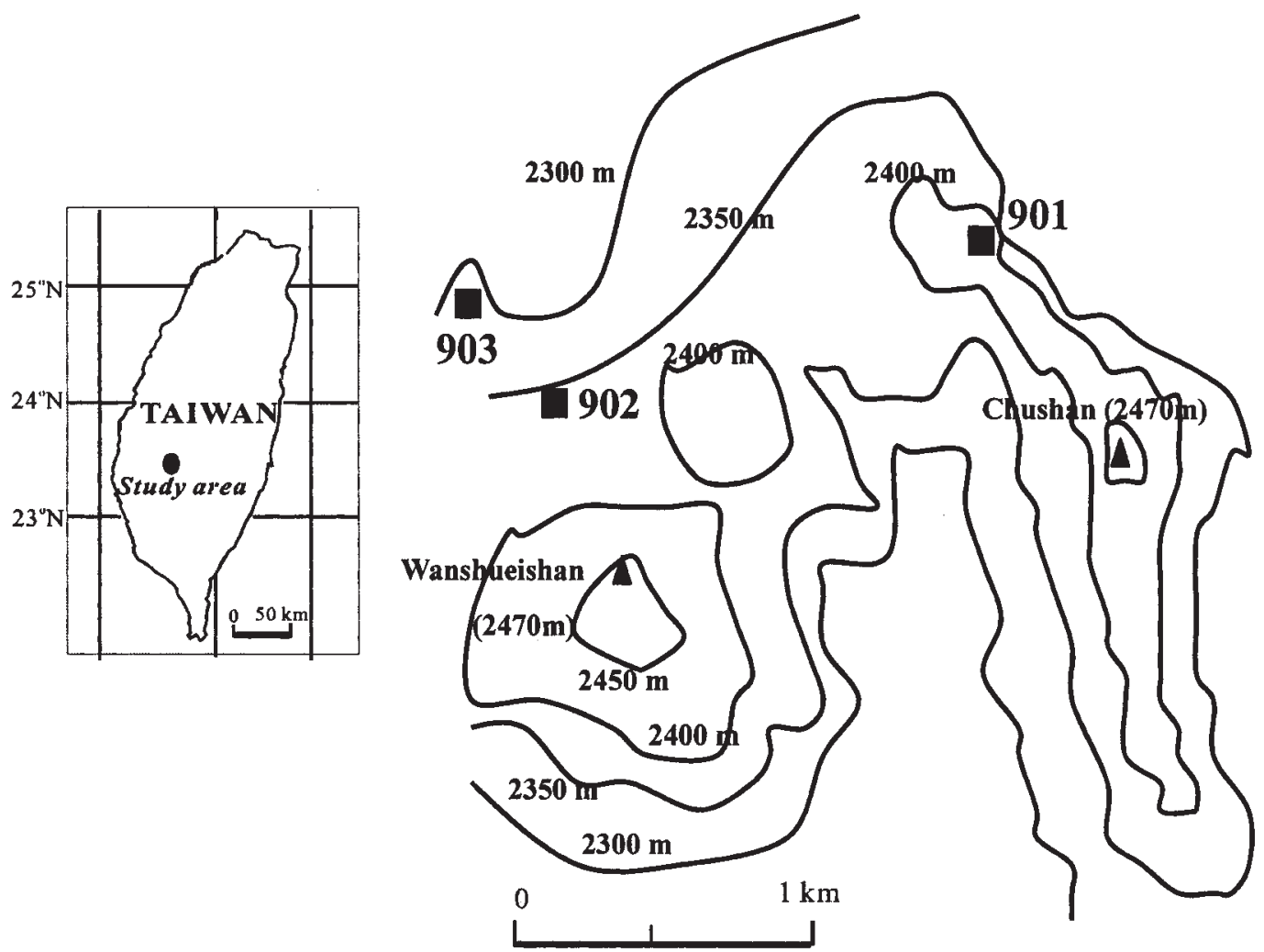

Fig. 1. Locations of the three pedons at the Alishan area, central Taiwan.

1982). Free $\mathrm{Fe}\left(\mathrm{Fe}_{\mathrm{d}}\right)$ and $\mathrm{Al}\left(\mathrm{Al}_{\mathrm{d}}\right)$ were extracted by the dithionite-citrate-bicarbonate (DCB) method (Mehra and Jackson, 1960). Amorphous and organic-bound forms of $\mathrm{Fe}\left(\mathrm{Fe}_{\mathrm{o}}\right)$ and $\mathrm{Al}\left(\mathrm{Al}_{\mathrm{o}}\right)$ were extracted by $0.2 \mathrm{M}$ ammonium oxalate $(\mathrm{pH} 3.0)$ (McKeague and Day, 1966). Organic-bound Fe $\left(\mathrm{Fe}_{\mathrm{p}}\right)$ and $\mathrm{Al}\left(\mathrm{Al}_{\mathrm{p}}\right)$ were extracted by $0.1 \mathrm{M}$ sodium pyrophosphate ( $\mathrm{pH} 10.0)$ (Loveland and Digby, 1984). Finally, contents of metal ions in the extracts were determined by atomic absorption spectrometry (Hitachi 180-30 type). Optical density of the oxalate extract (ODOE) was determined by the method developed by Daly (1982).

For micromorphological studies, Kubiena boxes were used to collect undisturbed soil blocks in the field. After air drying, vertical oriented thin sections with a thickness of $30 \mu \mathrm{m}$ were prepared by Spectrum Petrographics, Inc., Winston, Oregon. Thin sections were observed for all horizons using a polarized microscope and described according to the terminology of Bullock et al. (1985).

\section{Statistical Analysis}

The correlations between the amounts of clay, organic carbon, and extractions of $\mathrm{Fe}$ and $\mathrm{Al}$ were analyzed by ANOVA (SAS Institute, 1982). The statistical significance was defined at the level of $P=0.05$.

TABLE 1

Geographical information and classification of the three pedons

\begin{tabular}{llcccc}
\hline Pedon & Landscape position & Elevation & Slope & Aspect & Soil classification \\
\hline & & M & $\%$ & degree & \\
901 & Shoulder & 2,420 & 5 & 270 & Ultic Haplorthods \\
902 & Lower backslope & 2,370 & 9 & 0 & Ultic Haplorthods \\
903 & Lower backslope & 2,330 & 3 & 310 & Ultic Haplorthods \\
\hline
\end{tabular}

tSoil Taxonomy (Soil Survey Staff, 1999). 


\section{RESULTS AND DISCUSSION}

\section{Field Morphology}

Although the three pedons are located at different landscape positions, they are all classified as Spodosols with sequences of O-A-E-Bhs-C, based on criteria in Soil Taxonomy (Soil Survey Staff, 1999) (Table 1). Surface layers (O\&O/A) greater than $10 \mathrm{~cm}$ in thickness were found in all three Spodosols. Pedon 901 had a surface O horizon of nearly $30 \mathrm{~cm}$ (Table 2 ). The soil colors in all of the subsurface horizons with different degrees of spodic material accumulation are close to 7.5YR 5/6, which is defined in Soil Taxonomy as one of morphological criteria for spodic horizon (Bhs) (Soil Survey Staff, 1999). Various clay coatings and pellet-like aggregates were found in all of the subsurface horizons, which, in part, meets the criteria of spodic horizon (Bhs) (Li et al., 1998; Liu and Chen, 2004). Eluvial-illuvial phenomena were also clearly evidenced by changes in soil color and soil texture throughout the soil profiles. The colors were gray or light gray, with a chroma of 1 , in all eluvial horizons, but were strong brown or brownish yellow in the subsurface horizons. All albic horizons were sandy loam, but the spodic or argillic horizons were sandy clay loam to clay. The strong brown spodic horizons, found within $50-\mathrm{cm}$ depth, were underlain by similarly col-

TABLE 2

Morphological characteristics of the three pedons

\begin{tabular}{|c|c|c|c|c|c|c|c|c|c|}
\hline Horizon & Depth & Munsell color & Texturet & Structure $\ddagger$ & Consistence $\mathbb{S}$ & Biopores & Roots & Clay coatings $^{\#}$ & Boundary ${ }^{\dagger \dagger}$ \\
\hline \multicolumn{10}{|c|}{$\mathrm{cm}$} \\
\hline \multicolumn{10}{|c|}{ Pedon 901 (Ultic Haplorthods) } \\
\hline Oi & $28-0$ & $2.5 \mathrm{YR} 2.5 / 2$ & 一护 & - & - & - & - & - & - \\
\hline $\mathrm{Oe} / \mathrm{A}$ & $0-5$ & 5YR 2.5/1 & $\mathrm{scl}$ & $2 v f \& f g r$ & - & - & $\operatorname{mvf\& f}$ & - & as \\
\hline E & $5-11$ & 10YR 5/1 & $\mathrm{scl}$ & mas & fir & svf\&f & mvf\&f & - & cs \\
\hline Bhs & $11-17$ & $7.5 \mathrm{YR} 4 / 6$ & $\mathrm{scl}$ & $2 \mathrm{f} \& \mathrm{mabk}$ & fir & - & mvf\&f & df & $\mathrm{g}$ \\
\hline Bt1 & $17-42$ & 7.5YR 5/8 & $c$ & $2 \mathrm{f} \& \mathrm{mabk}$ & fri\&fir & svf\&f & comvf\&f, fm & df & d \\
\hline Bt2 & $42-67$ & $7.5 Y R 5 / 8$ & c & $2 \mathrm{f} \& \mathrm{mabk}$ & fri\&fir & svf\&f & comvf\&f, fin & dc & $\mathrm{d}$ \\
\hline Bt3 & $67-92$ & 7.5YR 5/8 & c & $2 \mathrm{f} \& \mathrm{mabk}$ & fir & svf\&f & fvf & $\mathrm{dc}$ & $\mathrm{d}$ \\
\hline $\mathrm{C}$ & $>92$ & 10YR 5/6 & sl & $2 \mathrm{f} \& \mathrm{mabk}$ & fri\&fir & fvf\&f & - & & - \\
\hline \multicolumn{10}{|c|}{ Pedon 902 (Ultic Haplorthods) } \\
\hline $\mathrm{Oi}$ & $4-0$ & $5 Y R 3 / 4$ & - & - & - & - & $m v f \& f, s m \& f c$ & - & cs \\
\hline $\mathrm{Oe} / \mathrm{A}$ & $0-8$ & $7.5 Y R 3 / 2$ & 1 & mvf\&fgr & fri & - & $\operatorname{mvf} \& 1, \mathrm{sm} \& \mathrm{c}$ & - & cs \\
\hline $\mathrm{Oa} / \mathrm{A}$ & $8-14$ & $5 Y R 2.5 / 1$ & $\mathrm{scl}$ & $2 v f \& f g r$ & fri & mvf\&f $n$ & $\operatorname{mvf} \& 1$, fin\&c & - & as \\
\hline \multirow[t]{2}{*}{ E } & $14-18$ & 7.5YR 6/1 (85\%) & sl & mas & fir & svf\&f & svf\&1, fin & - & as \\
\hline & & 7.5YR 5/8 (15\%) & & & & & & & \\
\hline Bhs & $18-30$ & $7.5 \mathrm{YR} 5 / 6$ & $\mathrm{scl}$ & 2vf\&fabk & fir & fvf & svf\& 1 , fin & df & $\mathrm{d}$ \\
\hline $\mathrm{Bt}$ & $30-46$ & 7.5YR 5/6 & $\mathrm{scl}$ & $2 \mathrm{f} \& \mathrm{mabk}$ & fir & fvf & svf\&1, fm & $\mathrm{dc}$ & as \\
\hline \multirow[t]{2}{*}{$2 \mathrm{E}$} & $46-53$ & 7.5YR 6/1(90\%) & sl & mas & fir & svf\&f & fvf\&f & - & as \\
\hline & & 10YR 5/6 (10\%) & & & & & & & \\
\hline $2 \mathrm{Bw}$ & $53-66$ & $10 Y R 5 / 6$ & $\mathrm{scl}$ & $2 \mathrm{f} \& \mathrm{mabk}$ & ss\&sp & fvf & - & & $\mathrm{d}$ \\
\hline $2 \mathrm{C}$ & $>66$ & & & & & & & & \\
\hline \multicolumn{10}{|c|}{ Pedon 903 (Ultic Haplorthods) } \\
\hline $\mathrm{Oe}$ & $10-0$ & 7.55YR 3/1 & - & - & - & - & $\operatorname{mvf\& 1,\mathrm {sm}}$ & - & cs \\
\hline A & $0-4$ & 7.5 YR $2.55 / 1$ & sI & $2 v f \& f g r$ & fri & - & $\operatorname{mvf} \& 1$, fin & - & as \\
\hline $\mathrm{E}$ & $4-13$ & 7.5YR 7/1 & sl & mas & fir & - & svf\&1, fm\&c & - & $\mathrm{cW}$ \\
\hline EB & $13-30$ & 7.5YR 7/1 & sl & mas & fir & fvf & svf\&1, fm & df & $\mathrm{d}$ \\
\hline \multirow[t]{2}{*}{ Bhs } & $30-44$ & 7.5YR 4/3 (50\%) & $\mathrm{scl}$ & 2vf, f\&mabk & s\&p & fvf\&f & svf\&f & df & $\mathrm{d}$ \\
\hline & & 7.5YR 5/6 (50\%) & & & & & & & \\
\hline $\mathrm{Bt}$ & $44-70$ & $10 \mathrm{YR} 5 / 6$ & $\mathrm{scl}$ & 2vf, f\&mabk & fir & fvf & svf & - & $\mathrm{d}$ \\
\hline $\mathrm{C}$ & $>70$ & 10YR 5/8 & $\mathrm{scl}$ & 2f\&mabk & fir & fvf & svf\&f & - & - \\
\hline
\end{tabular}

$\dagger 1=$ loam; $\mathrm{sl}=$ sandy loam; $\mathrm{cl}=$ clay loam; $\mathrm{scl}=$ sandy clay loam; $\mathrm{c}=$ clay; $\mathrm{sc}=$ sandy clay.

$\ddagger 2=$ moderate; $\mathrm{vf}=$ very fine, $\mathrm{f}=$ fine, $\mathrm{m}=$ medium, $\mathrm{c}=$ coarse; $\mathrm{g}=$ granular, $\mathrm{abl}=$ angular blocky, mas $=$ massive.

${ }_{\text {fri }}=$ friable, fir $=$ firm; $s$ = slightly sticky, $s p=$ slightly plastic.

$\tau_{\mathrm{m}}=$ many, $\mathrm{s}=$ some, $\mathrm{f}=$ few; $\mathrm{vf}=$ very fine, $\mathrm{f}=$ fine, $\mathrm{m}=$ medium, $\mathrm{c}=$ coarse .

${ }^{\#} \mathrm{df}=$ discontinuous few, $\mathrm{dc}=$ discontinuous common.

$\mathrm{t}_{\mathrm{a}}=$ abrupt, $\mathrm{c}=$ clear, $\mathrm{s}=$ smooth, $\mathrm{g}=$ gradual, $\mathrm{d}=$ diffuse, $\mathrm{w}=$ wavy.

\#No data. 
ored Bt horizons in the three pedons. The layer of organic matter of pedon 901 was more than $30 \mathrm{~cm}$ thick, including the Oi and Oe/A horizons. Pedon 902 was an Orthod, which had a spodic upper sequum (A-E-Bhs-Bt) overlying a sequence of $2 \mathrm{E}-2 \mathrm{Bw}-2 \mathrm{C}$ horizons. The only bisequal profile in the study resembles the Spodosol-Alfisol profiles in the glacial terrain in northeastern Michigan, which are coarser in texture (Schaetzl, 1996). It was difficult to identify clay coatings using the naked eye, but fragmental few and common clay coatings found in all Bhs and Bt horizons can be identified in the field by hand lens.

\section{Micromorphology}

The organic layers of the three pedons consist of flora fragments in varying states of decomposition. In thin sections, fresh roots, humified substances mixed with broken cell walls, fecal pellets, and/or amorphous organic materials were found in the $\mathrm{O}$ or $\mathrm{O} / \mathrm{A}$ horizons. Whereas clean coarse grains dominate the micromorphological characteristics of the E horizons, microstructures are associated with trace amounts of packing voids and cracks, roots, and black humidified materials (Table 3).

In the Bhs horizon of pedon 901, the domi-

TABLE 3

Micromorphological description of selected horizons in the three pedons

\begin{tabular}{|c|c|c|}
\hline Horizon & Distribution pattern; B-fabric; microstructure & Pedofeatures \\
\hline \multicolumn{3}{|c|}{ Pedon 901 (Ultic Haplorthods) } \\
\hline $\mathrm{Oe} / \mathrm{A}$ & $\begin{array}{l}\text { Enaulic; undifferentiated; granular with } \\
\text { minor spongy. }\end{array}$ & $\begin{array}{l}\text { Texture-unsorted silt and sand; fabric-common dense aggre- } \\
\text { gates of various sizes; few } 0.5-1.0 \mathrm{~mm} \text { charcoal fragments. }\end{array}$ \\
\hline $\mathrm{E}$ & $\begin{array}{l}\text { Porphyric; undifferentiated with minor } \\
\text { banded; compact grained. }\end{array}$ & $\begin{array}{l}\text { Texture - unsorted silt and sand; few } 10-50 \mu \mathrm{m} \text { siltans; depletion- } \\
\text { common albans along ped surface; amorphous-diffuse } \\
\text { organic stains and Fe mottles in the matrix. }\end{array}$ \\
\hline Bhs & $\begin{array}{l}\text { Chitonic to porphyric; undifferentiated } \\
\text { complex with minor subangular blocky. }\end{array}$ & $\begin{array}{l}\text { Texture - few moderately-oriented } 100-250 \mu \mathrm{m} \text { clay coatings; } \\
\text { amorphous - many dark brown } 20-500 \mu \mathrm{m} \text { organo-Fe } \\
\text { complex on the sand grain and pedsurface. }\end{array}$ \\
\hline Bt1 & $\begin{array}{l}\text { Porphyric; undifferentiated to reticulate } \\
\text { striated; complex with minor crack. }\end{array}$ & $\begin{array}{l}\text { Texture - few moderately and well-oriented } 50-500 \mu \mathrm{m} \text { clay } \\
\text { coatings; amorphous—-dark brown organo-Fe complex coated } \\
\text { on the pedsurface; fabric-dense plasma around sand and } \\
\text { primary coarse grain. }\end{array}$ \\
\hline $\mathrm{C}$ & $\begin{array}{l}\text { Chitonic to porphyric; undifferentiated with } \\
\text { dotted fine material; subangular blocky. }\end{array}$ & $\begin{array}{l}\text { Texture - rare } 50-100 \mathrm{~mm} \text { random clay and silt coatings on sand } \\
\text { grain; amorphous - few dark brown plasma infillings among } \\
\text { voids. }\end{array}$ \\
\hline \multicolumn{3}{|c|}{ Pedon 902 (Ultic Haplorthods) } \\
\hline $\mathrm{Oe} / \mathrm{A}$ & $\begin{array}{l}\text { Enaulic to chitonic; undifferentiated; } \\
\text { granular with minor spongy. }\end{array}$ & $\begin{array}{l}\text { Texture - unsorted silt and sand; fabric_-common dense } \\
\text { aggregates of various sizes; excrement-few 200-1000 } \mu \mathrm{m} \\
\text { ellipse fecal pettets mixed with organic fragments; common } \\
\text { 1-2 mm charcoal fragments. }\end{array}$ \\
\hline E & $\begin{array}{l}\text { Porphyric; undifferentiated to stipple- } \\
\text { speckled; massive. }\end{array}$ & $\begin{array}{l}\text { Texture - unsorted silt and sand, rare }<5 \mu \mathrm{m} \text { clay coatings on } \\
\text { the sand grain; depletion-common albans along root channel } \\
\text { and void; amorphous-few diffuse organic stains and Fe } \\
\text { mottles in the matrix. }\end{array}$ \\
\hline Bhs & $\begin{array}{l}\text { Chitonic to porphyric; undifferentiated to } \\
\text { stipple-speckled; complex with minor } \\
\text { subangular blocky. }\end{array}$ & $\begin{array}{l}\text { Texture-common moderately-oriented } 100-500 \mu \mathrm{m} \text { clay } \\
\text { coatings; amorphous - dark brown organo-Fe complex } \\
\text { infilled within matrix and on the pedsurface. }\end{array}$ \\
\hline Bt & $\begin{array}{l}\text { Porphyric; stipple and mosaic speckled; } \\
\text { subangular blocky and crack. }\end{array}$ & $\begin{array}{l}\text { Texture-few well-oriented } 50-500 \mu \mathrm{m} \text { clay coatings; } \\
\text { amorphous - many } 50-1000 \mu \mathrm{m} \text { dark dark brown organo-Fe } \\
\text { complex on the pedsurface. }\end{array}$ \\
\hline $2 \mathrm{E}$ & $\begin{array}{l}\text { Porphyric; undifferentiated to stipple- } \\
\text { speckled; massive. }\end{array}$ & $\begin{array}{l}\text { Texture- unsorted silt and sand, rare } 50-200 \mu \mathrm{m} \text { clay coatings } \\
\text { along root channel; depletion-common albans along root } \\
\text { channel and void; amorphous - rare faint light yellow Fe } \\
\text { mottles in the matrix. }\end{array}$ \\
\hline $2 \mathrm{Bw}$ & $\begin{array}{l}\text { Porphyric; undifferentiated; subangular } \\
\text { blocky with minor vughy. }\end{array}$ & $\begin{array}{l}\text { Texture-rare well-oriented } 100-500 \mu \mathrm{m} \text { clay coatings; fabric- } \\
\text { few weakly impregnated } 0.2-1 \mathrm{~mm} \text { nodules. }\end{array}$ \\
\hline
\end{tabular}


TABLE 3-Continued

Micromorphological description of selected horizons in the three pedons

\begin{tabular}{|c|c|c|}
\hline Horizon & Distribution pattern; B-fabric; microstructure & Pedofeatures \\
\hline \multicolumn{3}{|c|}{ Pedon 903 (Ultic Haplorthods) } \\
\hline A & $\begin{array}{l}\text { Enaulic; undifferentiated; granular with } \\
\text { minor spongy. }\end{array}$ & $\begin{array}{l}\text { Texture-unsorted silt and sand; fabric-common dense } \\
\text { aggregates of various sizes; amorphous-rare diffuse }<20 \mu \mathrm{m} \\
\text { Fe mottles on the coarse gram; excrement-few 200-1000 } \\
\mu \mathrm{m} \text { ellipse fecal pettets mixed with organic fragments. }\end{array}$ \\
\hline EB & $\begin{array}{l}\text { Porphyric; undifferentiated to stipple- } \\
\text { speckled; massive with minor crack. }\end{array}$ & $\begin{array}{l}\text { Texture-few moderately-oriented } 50-500 \mu \mathrm{m} \text { clay coatings; } \\
\text { depletion-common albans along root channel and void; } \\
\text { amorphous-few faint light yellow Fe mottles along root } \\
\text { channel. }\end{array}$ \\
\hline Bhs & $\begin{array}{l}\text { Chitonic to porphyric; undifferentiated; } \\
\text { subangular blocky. }\end{array}$ & $\begin{array}{l}\text { Texture-common moderately-oriented } 100-500 \mathrm{~mm} \text { clay } \\
\text { coatings in the chamber; amorphous - common diffuse dark } \\
\text { brown } 100-500 \mu \mathrm{m} \text { organo-Fe complex on the sand grain. }\end{array}$ \\
\hline Bt & $\begin{array}{l}\text { Porphyric; undifferentiated to stipple- } \\
\text { speckled; subangular blocky. }\end{array}$ & $\begin{array}{l}\text { Texture-rare well-oriented } 100-200 \mu \mathrm{m} \text { clay, amorphous-few } \\
\text { diffuse dark brown } 200-1000 \mu \mathrm{m} \text { organo-Fe complex on the } \\
\text { sand grain. fabric-dense plasma around the coarse fragments } \\
\text { and sand grain. }\end{array}$ \\
\hline
\end{tabular}

nant pedofeatures were organo-metallic complexes shown as pellets or pellets-like aggregates on the coarse grain and pedsurface (Fig. 2a). Few moderately and well oriented clay coatings were found on pedsurfaces associated with dark pelletlike aggregates in the B horizons (Table 3). Surprisingly, organo-metallic and clay accumulations were identified both as pellets and clay coatings. These illuvial clays, however, have a relatively weak birefringence masked by amorphous materials (Fig. 2b). Similarly, both organo-metallic complexes and clay coatings were found in all Bhs and Bt horizons. There were organo-metallic pellets in the voids and on the pedsurface of the Bhs horizon of pedon 902 (Fig. 2c). The dominant pedfeatures in the Bt horizon of pedon 902 were oriented clay coatings along root channels (Fig. 2d).

Illuvial clays were seen as various forms in subsurface horizons, e.g., grain coatings, hypocoatings along the root channels, and infillings in larger packing voids. These illuvial clays have a relatively weak birefringence caused by organometallic complexes, especially when in Bhs horizons (Fig. 2c). Grain coatings and large pellet-like aggregates, resulting from clay, $\mathrm{Fe}$, and organic matter mixtures (Fig. 2d), were found in the $\mathrm{Bt}$ horizons of pedons 901 and 902 . Pellety fabrics were found primarily in the Bhs horizons of the three pedons (Fig. 2e). The skeleton grains were either uncoated or coated to different degrees with materials similar in appearance to the aggregates in the typical loamy Spodosols (Phillips and FitzPatrick, 1999). These aggregates and coatings consisted of a mixture of fine mineral materials. Surprisingly, thick clay coatings in more than $1 \%$ of the area in thin section, darkened by organometallic complexes, were also found in all Bhs horizons (Fig. 2f). Based on the micromorphology, we can infer that the translocation of clay occurred prior to the illuviation of organometallic complexes in the subsurface horizons in this study.

\section{Physical and Chemical Properties}

The three pedons have fine textures in the subsurface horizons, especially in the Bt horizons of pedon 901 which has more than $400 \mathrm{~g} / \mathrm{kg}$ clay (Table 4). The $\mathrm{pH}$ values of all soils are less than 5.0, and those of all Bhs and Bt horizons are significantly lower than the maximum $\mathrm{pH}$ value defined for spodic materials $(\mathrm{pH} \leq 5.9)$. Organic $\mathrm{C}$ contents are greatest in the surface organic horizon, decrease in the $\mathrm{E}$ horizon, and increase in the Bhs horizon. The accumulation of clay and organic carbon in the subsurface horizon was caused primarily by strong leaching potential from very high rainfall in the study area, especially in the summer. Cation exchange capacity followed the same trend as OC. Extremely low base saturation of the soils ranged from 1 to $10 \%$ in all pedons because of dominantly acidic sandstone parent materials and a strong leaching environment.

The concentrations of extractable $\mathrm{Fe}$ and $\mathrm{Al}$ are normally higher in the $\mathrm{B}$ horizons compared with either the $\mathrm{E}$ or A horizons (Table 5). Van Ranst et al. (1997) found the orders of $\mathrm{Fe}$ and $\mathrm{Al}$ 
among the three extractants were $\mathrm{Fe}_{\mathrm{d}}>\mathrm{Fe}_{\mathrm{o}}>$ $\mathrm{Fe}_{\mathrm{p}}$ and $\mathrm{Al}_{\mathrm{d}}>\mathrm{Al}_{\mathrm{o}} \geq \mathrm{Al}_{\mathrm{p}}$ in cool tropical Spodosols in $\mathrm{R}$ wanda. However, the orders of $\mathrm{Fe}$ and $\mathrm{Al}$ in this study are variable. The DCB-extractable Fe contents in the three pedons were much higher than oxalate- and pyrophosphate- extractable ones identified by the $\mathrm{Fe}_{\mathrm{p}} / \mathrm{Fe}_{\mathrm{d}}$ and $\mathrm{Fe}_{\mathrm{o}} / \mathrm{Fe}_{\mathrm{d}}$ values. Most pyrophosphate-extractable $\mathrm{Fe}$ and $\mathrm{Al}$ contents were higher than oxalate ones within the same horizons. High ratios of $\mathrm{Fe}_{\mathrm{p}} / \mathrm{Fe}_{\mathrm{o}}$ and $\mathrm{Al}_{\mathrm{p}} / \mathrm{Al}_{\mathrm{o}}$ in the $\mathrm{B}$ horizons of the three pedons, more than 1.0, suggested that most of non-
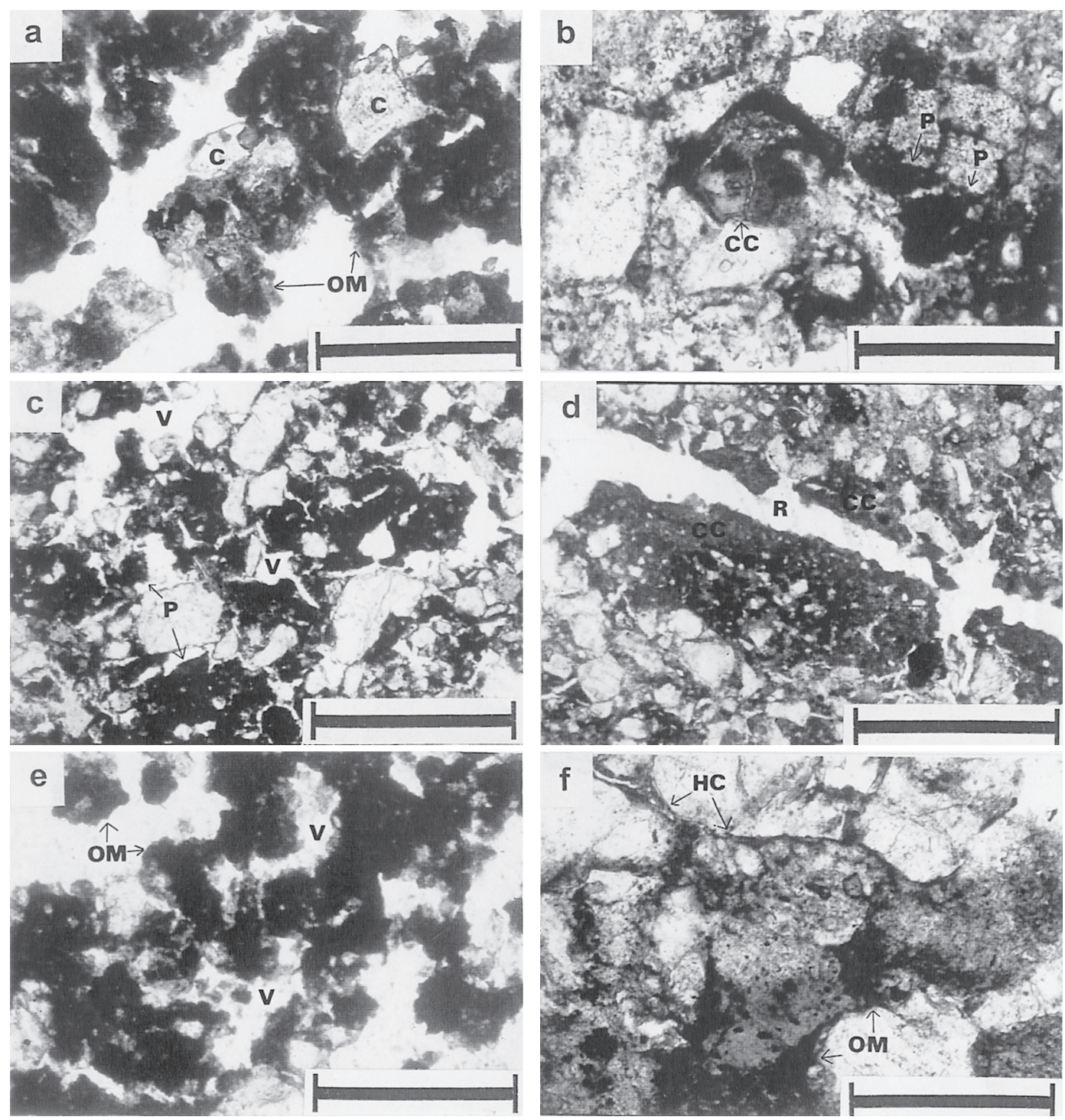

Fig. 2. Photomicrographs of the thin sections, plane polarized light: (a) isotropic dark aggregates composed of irregular organo-metallic complexes on the pedsurface and coarse grain. Frame length is $2.5 \mathrm{~mm}, \mathrm{OM}=$ organ-metallic complex, $\mathrm{C}=$ coarse grain, Bhs horizon, Pedon 901; (b) poorly-oriented clay coatings and pellet-like aggregates on the pedsurface. Frame length is $2.5 \mathrm{~mm}, \mathrm{CC}=$ clay coating, $\mathrm{P}=$ pellet, Bt1 horizon, Pedon 901 ; (c) isotropic dark pellets infilled in the void and coated on the sand grain. Frame length is $5.0 \mathrm{~mm}, \mathrm{~V}=$ void, $\mathrm{P}=$ pellet, Bhs horizon, Pedon 902; (d) well-oriented clay coatings along root channel. Frame length is $5.0 \mathrm{~mm}, \mathrm{CC}=$ clay coating, $R$ $=$ root channel, Bt horizon, Pedon 902; (e) organo-metallic complexes shown as dark smaller pellets in the void and larger aggregates on the pedsurface. Frame length is $2.5 \mathrm{~mm}, \mathrm{~V}=$ void, $\mathrm{OM}=$ organo-metallic complex, Bhs horizon, Pedon 903; (f) hypocoatings of clay in the wall of vugh and few organo-metallic complexes on the pedsurface. Frame length is $2.5 \mathrm{~mm}, \mathrm{HC}=$ hypocoating, $\mathrm{OM}=$ organo-metallic complex, Bhs horizon, Pedon 903. 
TABLE 4

The selected physical and chemical properties of the three pedons

\begin{tabular}{|c|c|c|c|c|c|c|c|c|c|}
\hline \multirow[b]{2}{*}{ Horizon } & \multirow[b]{2}{*}{ Depth } & \multirow[b]{2}{*}{$\mathrm{Bd}^{\dagger}$} & \multicolumn{3}{|c|}{ Texture } & \multirow[b]{2}{*}{$\mathrm{pH}$} & \multirow[b]{2}{*}{$\mathrm{OC}^{\ddagger}$} & \multirow[b]{2}{*}{$\mathrm{CEC}^{\S}$} & \multirow[b]{2}{*}{$\mathrm{BS}$} \\
\hline & & & Sand & Silt & Clay & & & & \\
\hline & $\mathrm{cm}$ & $\mathrm{Mg} / \mathrm{m}^{3}$ & ----- & $\mathrm{g} / \mathrm{kg}$ & ------ & & $\mathrm{g} / \mathrm{kg}$ & $\operatorname{cmol}(+) / \mathrm{kg}$ & $\%$ \\
\hline \multicolumn{10}{|c|}{ Pedon 901 (Ultic Haplorthods) } \\
\hline Oi & $28-0$ & — & - & - & - & 3.5 & 374 & 76.4 & 1 \\
\hline $\mathrm{Oe} / \mathrm{A}$ & $0-5$ & - & 519 & 278 & 203 & 3.5 & 149 & 35.7 & 2 \\
\hline $\mathrm{E}$ & $5-11$ & - & 568 & 204 & 228 & 3.7 & 18 & 21.5 & 3 \\
\hline Bhs & $11-17$ & - & 491 & 184 & 325 & 4.2 & 32 & 30.5 & 2 \\
\hline Bt1 & $17-42$ & - & 395 & 188 & 417 & 4.8 & 23 & 22.1 & 2 \\
\hline $\mathrm{Bt} 2$ & $42-67$ & 1.3 & 390 & 166 & 443 & 4.9 & 23 & 13.1 & 3 \\
\hline $\mathrm{Bt} 3$ & $67-92$ & 1.3 & 430 & 153 & 416 & 4.9 & 17 & 9.0 & 5 \\
\hline $\mathrm{C}$ & $>92$ & 1.2 & 598 & 230 & 172 & 4.9 & 12 & 7.0 & 6 \\
\hline \multicolumn{10}{|c|}{ Pedon 901 (Ultic Haplorthods) } \\
\hline Oi & 4-0 & - & - & - & - & 3.8 & 277 & 51.0 & 2 \\
\hline $\mathrm{Oe} / \mathrm{A}$ & $0-8$ & - & 428 & 310 & 262 & 4.0 & 145 & 38.7 & 2 \\
\hline $\mathrm{Oa} / \mathrm{A}$ & $8-14$ & - & 456 & 245 & 300 & 3.5 & 89 & 36.5 & 3 \\
\hline E & $14-18$ & 1.2 & 560 & 246 & 190 & 4.0 & 15 & 11.8 & 6 \\
\hline Bhs & $18-30$ & 1.2 & 490 & 266 & 244 & 4.4 & 22 & 15.8 & 4 \\
\hline $\mathrm{Bt}$ & $30-46$ & 1.2 & 478 & 199 & 324 & 4.6 & 18 & 12.0 & 5 \\
\hline $2 \mathrm{E}$ & $46-53$ & - & 515 & 307 & 178 & 4.7 & 3 & 13.7 & 4 \\
\hline $2 \mathrm{Bw}$ & $53-66$ & - & 500 & 253 & 247 & 4.7 & 13 & 13.6 & 5 \\
\hline \multicolumn{10}{|c|}{ Pedon 902 (Ultic Haplorthods) } \\
\hline Oe & $10-0$ & - & - & - & - & 4.4 & 82 & 19.7 & 10 \\
\hline A & $0-4$ & - & 604 & 254 & 142 & 3.9 & 31 & 14.3 & 10 \\
\hline $\mathrm{E}$ & $4-13$ & - & 635 & 240 & 126 & 4.4 & 8 & 14.1 & 9 \\
\hline EB & $13-30$ & 1.6 & 574 & 254 & 171 & 4.5 & 10 & 17.0 & 7 \\
\hline Bhs & $30-44$ & 1.1 & 490 & 232 & 288 & 4.5 & 26 & 21.6 & 7 \\
\hline $\mathrm{Bt}$ & $44-70$ & - & 454 & 266 & 280 & 4.5 & 22 & 19.1 & 7 \\
\hline
\end{tabular}

†Bulk density.

¥Organic carbon.

SCation exchange capacity.

IBase saturation percentage.

秋ot determined.

crystalline $\mathrm{Fe}$ and $\mathrm{Al}$ exists in organic-bound form. Bockheim et al. (1996) also showed a similar trend between these two extractions for Ultic Spodosols in Oregon, but their average ODOE values of the subsurface horizons were much less than those of this study.

Combinations or ratios of extractable Fe and Al can be used to interpret the degree of podzolization. Accumulation of spodic materials was identified by the values of $\mathrm{Al}_{\mathrm{o}}+1 / 2 \mathrm{Fe}_{\mathrm{o}}(\%)$ and ODOE (De Coninck, 1980). In the three pedons, these two parameters satisfied the criteria defined in spodic material based on Soil Taxonomy criteria (Soil Survey Staff, 1999) and indicated that strong podzolization processes had occurred. The values of $\mathrm{Al}_{\mathrm{o}}+1 / 2 \mathrm{Fe}_{\mathrm{o}}(\%)$ in the Bhs horizons were much greater than twice those in the upper layers. The depth functions of ODOE values correlated well with OC content in this study ( $\mathrm{Ta}-$ bles 4 and 5). The spodic horizons of these soils have reddish hues (7.5YR) and high levels of oxalate extractable $\mathrm{Fe}$ and $\mathrm{Al}$ and illuvial $\mathrm{OC}$, as reflected by ODOE values in excess of 0.25 . The ODOE test was designed to indicate the presence of fulvic acids that are crucial to the translocation of Fe and $\mathrm{Al}$ in Spodosols (Daly, 1982). Therefore, in this study, fulvic acids might play a role as major chelating agents for transporting $\mathrm{Fe}$ and $\mathrm{Al}$ associated with relatively high ODOE values in the Bhs horizons.

All of the Bt and Bhs horizons satisfied the chemical criteria defined in spodic horizons from the keys to Soil Taxonomy. Pyrophosphate extractable $\mathrm{Fe}$ and $\mathrm{Al}$ values correlated well with OC values $\left(r^{2}=0.71\right.$ and $\left.0.38 ; P<0.05\right)$ for all of the eluvial and illuvial horizons $(n=15)$ of the three pedons. Our results further indicated that the clay content correlated well not only with pyrophosphate extractable Fe and $\mathrm{Al}\left(r^{2}=0.68\right.$ and $0.74 ; P<0.05)$ but also with dithionite cit- 
TABLE 5

The selected $\mathrm{Fe}$ and $\mathrm{Al}$ properties of the three pedons

\begin{tabular}{|c|c|c|c|c|c|c|c|c|c|c|c|c|c|}
\hline Horizon & Depth & $\mathrm{Fe}_{\mathrm{d}}^{\dagger}$ & $\mathrm{Al}_{\mathrm{d}}$ & $\mathrm{Fe}_{\mathrm{o}}^{\dagger}$ & $\mathrm{Al}_{\mathrm{o}}$ & $\mathrm{Fe}_{\mathrm{p}}^{\dagger}$ & \multicolumn{3}{|c|}{$\mathrm{Al}_{\mathrm{p}} \mathrm{Al}_{\mathrm{o}}^{\dagger}(1 / 2) \mathrm{Fe}_{\mathrm{o}} \mathrm{Fe}_{\mathrm{p}} / \mathrm{Fe}_{\mathrm{o}}$} & $\mathrm{Fe}_{\mathrm{p}} / \mathrm{Fe}_{\mathrm{d}}$ & $\mathrm{Fe}_{\mathrm{o}} / \mathrm{Fe}_{\mathrm{d}}$ & $\mathrm{Al}_{\mathrm{p}} / \mathrm{Al}_{\mathrm{o}}$ & $\mathrm{ODOE}^{\ddagger}$ \\
\hline & $\mathrm{cm}$ & ----- & $-{ }_{-}$ & $-\mathrm{g} / \mathrm{kg}$ & ----- & ------ & \multirow{2}{*}{\multicolumn{3}{|c|}{-----\%---- }} & & & & \\
\hline \multicolumn{11}{|c|}{ Pedon 901 (Ultic Haplorthods) } & & & \\
\hline $\mathrm{O}$ & $28-0$ & — & - & - & - & - & - & - & - & - & - & - & 0.77 \\
\hline $0 / \mathrm{A}$ & $0-5$ & 25.6 & 1.7 & 2.21 & 1.75 & 0.71 & 0.54 & 0.29 & 0.32 & 0.03 & 0.09 & 0.31 & 1.77 \\
\hline E & $5-11$ & 42.8 & 2.1 & 9.13 & 2.17 & 6.46 & 1.77 & 0.67 & 0.71 & 0.15 & 0.21 & 0.81 & 1.43 \\
\hline Bhs & $11-17$ & 60.2 & 19.6 & 16.9 & 6.10 & 33.4 & 6.99 & 1.46 & 1.97 & 0.55 & 0.28 & 1.15 & 3.03 \\
\hline $\mathrm{Bt} 1$ & $17-42$ & 62.5 & 24.7 & 17.4 & 8.62 & 23.7 & 9.42 & 1.73 & 1.36 & 0.38 & 0.28 & 1.09 & 2.00 \\
\hline Bt2 & $42-67$ & 66.1 & 15.8 & 11.9 & 6.02 & 13.0 & 6.45 & 1.20 & 1.09 & 0.20 & 0.18 & 1.07 & 2.01 \\
\hline Bt3 & $67-92$ & 51.9 & 12.9 & 7.02 & 4.31 & 8.22 & 4.54 & 0.78 & 1.17 & 0.16 & 0.14 & 1.05 & 0.94 \\
\hline $\mathrm{C}$ & $>92$ & 44.3 & 3.8 & 3.07 & 2.27 & 0.75 & 1.40 & 0.38 & 0.25 & 0.02 & 0.07 & 0.62 & 0.13 \\
\hline \multicolumn{14}{|c|}{ Pedon 902 (Ultic Haplorthods) } \\
\hline Oi & $4-0$ & - & - & - & - & - & - & - & - & - & - & - & 0.52 \\
\hline $\mathrm{Oe} / \mathrm{A}$ & $0-8$ & 32.6 & 2.2 & 4.93 & 1.77 & 4.64 & 1.88 & 0.42 & 0.94 & 0.14 & 0.15 & 1.06 & 2.19 \\
\hline $\mathrm{Oa} / \mathrm{A}$ & $8-14$ & 23.1 & 1.7 & 4.98 & 2.42 & 3.94 & 2.12 & 0.49 & 0.79 & 0.17 & 0.22 & 0.88 & 2.28 \\
\hline $\mathrm{E}$ & $14-18$ & 37.6 & 1.3 & 5.96 & 1.50 & 3.67 & 1.10 & 0.45 & 0.62 & 0.10 & 0.16 & 0.73 & 0.57 \\
\hline Bhs & $18-30$ & 59.2 & 4.6 & 15.1 & 3.00 & 15.6 & 3.99 & 1.05 & 1.03 & 0.26 & 0.25 & 1.33 & 1.48 \\
\hline $\mathrm{Bt}$ & 3046 & 42.2 & 4.1 & 10.2 & 3.66 & 13.8 & 4.15 & 0.88 & 1.35 & 0.33 & 0.24 & 1.13 & 1.17 \\
\hline $2 \mathrm{E}$ & $46-53$ & 18.5 & 0.7 & 0.74 & 0.74 & 0.44 & 0.62 & 0.11 & 0.59 & 0.02 & 0.04 & 0.84 & 0.08 \\
\hline $2 \mathrm{Bw}$ & $53-66$ & 56.5 & 5.3 & 12.0 & 4.53 & 12.3 & 4.88 & 1.05 & 1.03 & 0.22 & 0.21 & 1.08 & 1.20 \\
\hline \multicolumn{14}{|c|}{ Pedon 903 (Ultic Haplorthods) } \\
\hline \multicolumn{14}{|l|}{0.66} \\
\hline A & $0-4$ & 18.8 & 0.9 & 2.80 & 0.97 & 1.34 & 0.86 & 0.24 & 0.48 & 0.07 & 0.15 & 0.88 & 0.62 \\
\hline $\mathrm{E}$ & $4-13$ & 18.4 & 0.4 & 0.68 & 0.38 & 0.28 & 0.28 & 0.07 & 0.41 & 0.02 & 0.04 & 0.73 & 0.20 \\
\hline $\mathrm{EB}$ & $13-30$ & 33.3 & 0.9 & 1.78 & 1.08 & 1.90 & 0.83 & 0.20 & 1.07 & 0.06 & 0.05 & 0.76 & 0.11 \\
\hline Bhs & $30-44$ & 61.2 & 12.9 & 14.5 & 4.96 & 17.3 & 5.16 & 1.22 & 1.20 & 0.28 & 0.24 & 1.04 & 2.35 \\
\hline $\mathrm{Bt}$ & $44-70$ & 72.5 & 7.2 & 11.6 & 5.34 & 19.3 & 5.58 & 1.12 & 1.66 & 0.27 & 0.16 & 1.05 & 1.13 \\
\hline
\end{tabular}

tSubscripted $\mathrm{d}, \mathrm{o}$ and $\mathrm{p}$ are citrate-dithionite, oxalate and pyrophosphate extractable.

‡Optical density of oxalate extraction.

\#Not determined.

rate extractable $\mathrm{Fe}$ and $\mathrm{Al}\left(r^{2}=0.65\right.$ and $0.73 ; P$ $<0.05)$. The high $r^{2}$ values suggest that illuvial Fe and $\mathrm{Al}$ are significantly bound with organic matter and then leached downward with clay. Therefore, although these organo-metallic complexes may adsorb or precipitate within the finer matrix formed by the illuvial particles, they move down only for a short distance.

\section{Pedogenic Processes}

Clay translocation and spodic material illuviation occurred in these soils as identified by field morphology, micromorphology, and laboratory analysis. Based on the formation of Bt and Bhs horizons in the Alishan area, we hypothesize that Spodosols associated with clay illuviation were formed locally in the flatter microrelief $(<10 \%$ in slope), where organic matter is easily deposited in humid climate. Clay translocation is generally attributed to the washing of clay in suspension by heavy rainfall in a humid tropical environment. Therefore, in this study, clay coatings were the dominant pedofeatures in the lower parts of the pedons. Because coniferous trees were formed as the dense stand vegetation, organo-metallic complexes accumulated progressively on the surface of illuvial clays or coagulated as spodic pellets in the subsurface horizons. The above hypothesis is evidenced by organo-metallic complexes accumulated on the surface of clay coatings (Figs. 2b and $2 \mathrm{f}$ ). Illuviation of spodic material is currently active, but organic-metallic complexes accumulate slowly in the Bhs horizons within a $50-\mathrm{cm}$ depth, attributed to fine texture and less porosity. The soils derived from polypedogenic processes to show transitional status between Ultisols and Spodosols in this study are similar to the hybrid soils reported by Markewich and Pavich (1991) in the eastern United States.

\section{CONCLUSION}

Illuviations of clay, $\mathrm{Fe}, \mathrm{Al}$, and organic carbon were clearly identified by field morphology, mi- 
cromorphology, and physical and chemical properties in this study. Despite the large amounts of illuvial clays as various coatings in the Bt and Bhs horizons, their birefringence was weakened by the illuviation of organo-metallic complexes. The soil colors are almost 7.5YR 5/6 in all of the subsurface horizons, with various degrees of spodic material accumulation even though all of the chemical properties in the Bt horizons satisfied the criteria of a spodic horizon. Translocation of clay was regarded as the major pedogenic process in the earlier soil development, but podzolization became more currently active when the dense coniferous vegetation formed. Organo-metallic complexes were translocated, and large amounts were deposited in the upper part of the subsurface horizon, particularly within $50 \mathrm{~cm}$ depth. We conclude that coniferous vegetation and very high precipitation strongly influence the pedogenic processes of the Ultisol-Spodosols in the Alishan area. A large amount of rainfall $(>4000 \mathrm{~mm} / \mathrm{yr})$ accelerated the spodic material illuviation in the fine textured soils. Spodosols are found only in some flat areas in the microrelief of Alishan Mountain, where litter is easily accumulated to produce large amounts of humic substance that may form organic-metallic complexes.

\section{REFERENCES}

Alekseyev, V. Y. 1983. Mineralogical analysis for the determination of podzolization, lessivage and argillation. Sov. Soil Sci. 15:21-28.

Blake, G. R., and K. H. Hartge. 1986. Bulk density. In Methods of Soil Analysis, Part 1. 2nd Ed. A. Klute (ed.). Agron. Monogr. No. 9. ASA and SSSA, Madison, WI, pp. 383-411.

Bockheim, J. G., H. M. Kelsey, and J. G. Marshall III. 1992. Soil development, relative dating, and correlation of late Quaternary marine terraces in southwestern Oregon. Quat.Res. 37:60-74.

Bockheim, J. G., J. G. Marshall III, and H. M. Kelsey. 1996. Soil-forming processes and rates on uplifted marine terrace in southwestern Oregon, USA. Geoderma 73:39-62.

Bullock, P., N. Fedoroff, A. Jongerius, G. Stoops, and T. Tursina. 1985. Handbook for Thin Section Description. Waine Res. Publ., Albrighton, England.

Chen, Z. S., J. C. Liu, and H. C. Chiang. 1995. Soil properties, clay mineralogy, and genesis of some alpine forest soils in the Ho-Huan Mountain area of Taiwan. J. Chin. Agric. Chem. Soc. 33:1-17.

Chen, Z. S., K. C. Lin, and J. M. Chang. 1989. Soil characteristics, pedogenesis, and classification of Beichateinshan Podzolic soils, Taiwan. J. Chin. Agric. Chem. Soc. 27:145-155. (in Chinese, with English abstract)

Daly, B. K. 1982. Identification of Podzol and pod- zolized soils in New Zealand by relative absorbance of oxalate extracts of A and B horizons. Geoderma 28:29-38.

De Coninck, F. 1980. Major mechanisms in formation of spodic horizons. Geoderma 24:101-128.

Farmer, V. C. 1982. Significance of the presence of allophane and imogolite in Podzol Bs horizons for podzolization mechanisms: A review. Soil Sci. Plant Nutr. 28:571-578.

Fridland, V. M. 1958. Podzolization and illimerization (clay migration). Sov. Soil Sci. 1:24-32.

Gee, G. W., and J. W. Bauder. 1986. Particle-size analysis. In Methods of Soil Analysis, Part 1, 2nd Ed. A. Klute (ed.). Agron. Monogr. No. 9. ASA and SSSA, Madison, WI, pp. 383-411.

Guillet, B. J., T. Rouiller, and B. Souchier. 1975. Podzolization and clay migration in Spodosols of eastern France. Geoderma. 14:223-245.

Harris, W. G., and K. A. Hollien. 1999. Changes in quantity and composition of crystalline clay across E-Bh boundaries of Alaquods. Soil Sci. 164:602608.

Hseu, Z. Y., Z. S. Chen, and Z. D. Wu. 1999. Characterization of placic horizons in two subalpine forest Inceptisols. Soil Sci. Soc. Am. J. 63:941-947.

Jakobsen, B. H. 1991. Multiple processes in the formation of subarctic podzols in Greenland. Soil Sci. 152:414-426.

Li, S. Y., Z. S. Chen, and J. C. Liu. 1998. Subalpine loamy Spodosols in Taiwan: Characteristics, micromorphology, and genesis. Soil Sci. Soc. Am. J. 62: 710-716.

Lin, C. W., Z. Y. Hseu, and Z. S. Chen. 2002. Clay mineralogy of Spodosols with fine textures in the subalpine forest soils of Taiwan. Clays Clay Miner. 50:726-735

Liu, J. C., and Z. S. Chen. 2004. Soil characteristics and clay mineralogy of two subalpine forest Spodosols with clay accumulation in Taiwan. Soil Sci. 169: 66-80.

Loveland, P. J., and P. Digby. 1984. The extraction of Fe and Al by $0.1 M$ pyrophosphate solutions: A comparison of some techniques. J. Soil Sci. 35:243-250.

Lundstrom, U. S., N. van Breemen, and D. Bain. 2000. The podzolization processes: A review. Geoderma 94:91-108.

Markewich, H. W., and M. J. Pavich. 1991. Soil chronosequence studies in temperate to subtropical, low-latitude, low-relief terrain with data from the eastern United States. Geoderma 51:213-239.

McKeague, J. A., and J. H. Day. 1966. Dithionite and oxalate extractable $\mathrm{Fe}$ and $\mathrm{Al}$ as aids in differentiating various classes of soils. Can.J. Soil Sci. 46:13-22.

McKeague, J. A., F. De Coninck, and D. P. Franzmeier. 1983. Spodosols. In Pedogenesis and Soil Taxonomy: II. The Soil Orders. L.P. Wilding, N.E. Smeck, and G.F. Hall (eds.). Elsevier, New York, pp. 217252.

McLean, E. O. 1982. Soil $\mathrm{pH}$ and lime requirement. In 
Methods of Soil Analysis, Part 2. 2nd Ed. A.L. Page et al. (eds.). Agron. Monogr. No. 9. ASA and SSSA, Madison, WI, pp. 199-224.

Mehra, O. P., and M. J. Jackson. 1960. Iron oxides removed from soils and clays by a dithionite-citrate system buffered with sodium bicarbonate. Clays Clay Miner. 7:317-327.

Miller, B. J. 1983. Ultisols. In: Pedogenesis and Soil Taxonomy: II. The Soil Orders. L.P. Wilding, N.E. Smeck, and G.F. Hall (eds.). Elsevier, New York, pp. 283-323.

Muir, A. 1961. The podzol and podzolic soils. Adv. Agron. 13:1-57.

Nelson, D. W., and L. E. Sommers. 1982. Total carbon, OC, and organic matter. In Methods of Soil Analysis, Part 2. 2nd Ed. A.L. Page et al. (eds.). Agron. Monogr. No.9. ASA and SSSA, Madison, WI, pp. 539-577.

Padley, E. A., L. J. Bartelli, and C. C. Trettin. 1985 Spodic horizon criteria applied to soils of northern Michigan. Soil Sci. Soc. Am. J. 49:401-405.

Phillips, D. H., and E. A. FitzPatrick. 1999. Biological influences on the morphology and micromorphology of selected Podzols (Spodosols) and Cambisols (Inceptisols) from the eastern United States and north-east Scotland. Geoderma 90:327-364.

Rhoades, J. D. 1982. Cation exchange capacity. In Methods of Soil Analysis, Part 2, 2nd Ed. A.L. Page et al. (eds.). Agron. Monogr. No. 9. ASA and SSSA, Madison, WI, pp. 149-157.

Righi, D., S. Bravard, A. Chauvel, J. Ranger, and M. Robert. 1990. In situ study of soil processes in an Oxisol-Spodosol sequence of Amazonia (Brazil). Soil Sci. 150:438-445.

Rourke, R. V., B. R. Brasher, R. D. Yeck, and F. T. Miller. 1988. Characteristic morphology of U. S. Spodosols. Soil Sci. Soc. Am. J. 52:445-449.

SAS Institute. 1982. SAS User's Guide. Statistics. SAS Institute, Cary, NC.

Schaetzl, R. J. 1996. Spodosol-Alfisol intergrades: Bisequal soils in NE Michigan, USA. Geoderma 74:2347.

Soil Survey Staff. 1993. Examination and description of soils in the field. In Soil Survey Manual. Handbook No. 18. USDA-SCS, Washington, DC, pp. 56-196.

Soil Survey Staff. 1999. Soil taxonomy: A basic system of soil classification for making and interpreting soil surveys. USDA-NRCS, Agricultural Handbook No. 436, 2nd Ed., U.S. Govt. Prining. Office, Washington, DC.

Van Ranst, E., G. Stoops, A. Gallez, R. E. Vandenberghe. 1997. Properties, some criteria of classification and genesis of upland forest Podzols in Rwanda. Geoderma 76:263-283. 